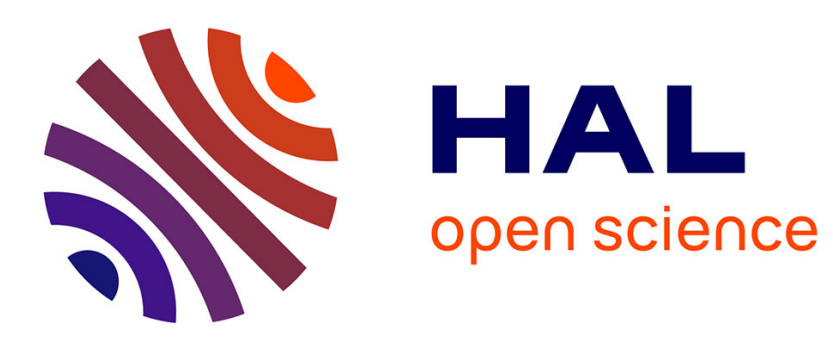

\title{
Magnetic susceptibility of some organometallic compounds of neptunium (IV)
}

\author{
A. Stollenwerk, R. Klenze, B. Kanellakopulos
}

\section{To cite this version:}

A. Stollenwerk, R. Klenze, B. Kanellakopulos. Magnetic susceptibility of some organometallic compounds of neptunium (IV). Journal de Physique Colloques, 1979, 40 (C4), pp.C4-179-C4-180. 10.1051/jphyscol:1979456 . jpa-00218852

\section{HAL Id: jpa-00218852 https://hal.science/jpa-00218852}

Submitted on 1 Jan 1979

HAL is a multi-disciplinary open access archive for the deposit and dissemination of scientific research documents, whether they are published or not. The documents may come from teaching and research institutions in France or abroad, or from public or private research centers.
L'archive ouverte pluridisciplinaire HAL, est destinée au dépôt et à la diffusion de documents scientifiques de niveau recherche, publiés ou non, émanant des établissements d'enseignement et de recherche français ou étrangers, des laboratoires publics ou privés. 


\title{
Magnetic susceptibility of some organometallic compounds of neptunium (IV)
}

\author{
A. H. Stollenwerk, R. Klenze and B. Kanellakopulos \\ Kernforschungszentrum Karlsruhe GmbH, Institut für Heisse Chemie, B.R.D. and Fachbereich Physíkalische Chemie, \\ Universität Heidelberg, B.R.D.
}

Résumé. - Les composés du neptunium tétravalent avec le cyclopentadiényle, $\left(\mathrm{C}_{5} \mathrm{H}_{5}\right)_{3} \mathrm{NpX}(\mathrm{X}=\mathrm{F}, \mathrm{Cl}, \mathrm{Br}, \mathrm{I}$, $\left.\left(\mathrm{SO}_{4}\right)_{1 / 2}\right)$, ont été préparés et étudiés. Nous discutons les mesures de susceptibilité magnétique dans le domaine de températures de $1 \mathrm{~K}$ à la température ambiante. Cette analyse donne des informations relatives au niveau électronique fondamental ${ }^{4} \mathrm{I}_{9 / 2}$ du cation $\mathrm{Np}(\mathrm{IV})$ sous l'influence du champ des ligands.

\begin{abstract}
A series of cyclopentadienyl compounds of the tetravalent neptunium, $\left(\mathrm{C}_{5} \mathrm{H}_{5}\right)_{3} \mathrm{NpX}$ with $\mathrm{X}=\mathrm{F}$, $\mathrm{Cl}, \mathrm{Br}, \mathrm{I},\left(\mathrm{SO}_{4}\right)_{1 / 2}$, have been prepared and investigated. Magnetic susceptibility measurements of all compounds in the temperature range from room temperature down to $1 \mathrm{~K}$ give information about the electronic ground state ${ }^{4} I_{9 / 2}$ of the $\mathrm{Np}(\mathrm{IV})$-ion split by crystal field. The temperature dependence of the magnetic susceptibility of the complexes is discussed.
\end{abstract}

1. Introduction. - In recent years considerable progress has been made in the interpretation of the physico-chemical properties of a series of $\left(\mathrm{C}_{5} \mathrm{H}_{5}\right)_{3} \mathrm{UX}$ compounds with a large variation in the ligand $\mathrm{X}$. Although these compounds have rather poor symmetry, it has been shown that a restricted set of calculation parameters is sufficient for a simultaneous interpretation of spectroscopic, magnetic susceptibility and NMR spectroscopic data [1].

Contrary to the $\left(\mathrm{C}_{5} \mathrm{H}_{5}\right)_{3} \mathrm{UX}$ compounds which have a non-magnetic ground state, the analogous neptunium compounds are expected to have a magnetic ground state, which provides additional information from magnetic measurements at low temperatures.

This has been demonstrated for the highly symmetric actinide compounds $\left[\left(\mathrm{C}_{2} \mathrm{H}_{5}\right)_{4} \mathrm{~N}\right]_{4} \mathrm{An}(\mathrm{NCS})_{8}[2,3]$, with $A n=T h, U, N p$. While in the case of the uranium compound the electronic ground state is strongly affected by Jahn-Teller distortion, the electronic ground state of the neptunium complex is not distorted.

This fact leads us to the conclusion that studies on the $\left(\mathrm{C}_{5} \mathrm{H}_{5}\right)_{3} \mathrm{NpX}$ series should be even more promising.

2. Preparation of the compounds. - The $\left(\mathrm{C}_{5} \mathrm{H}_{5}\right)_{3} \mathrm{NpX}$ compounds, where $\mathrm{X}=\mathrm{Cl}, \mathrm{Br}, \mathrm{I}$, $\left(\mathrm{SO}_{4}\right)_{1 / 2}$, were prepared by reacting $\mathrm{Np}\left(\mathrm{C}_{5} \mathrm{H}_{5}\right)_{4}$ with a stoichiometric amount of the respective ammonium salts [4]. The starting material, $\mathrm{Np}\left(\mathrm{C}_{5} \mathrm{H}_{5}\right)_{4}$, was prepared from the reaction of $\mathrm{NpCl}_{4}$ with an excess of $\mathrm{K}\left(\mathrm{C}_{5} \mathrm{H}_{5}\right)$ [5]. $\left(\mathrm{C}_{5} \mathrm{H}_{5}\right)_{3} \mathrm{NpF}$ was obtained by reacting a mixture of $\left(\mathrm{C}_{5} \mathrm{H}_{5}\right)_{3} \mathrm{NpCl}$ with an excess of $\mathrm{NaF}$ at $300{ }^{\circ} \mathrm{C}$ for 40 hours in a sealed glass tube and then extracting with tetrahydrofuran.
3. Magnetic susceptibility measurements. - Magnetic susceptibility data on all the neptunium compounds were obtained from $300 \mathrm{~K}$ down to $1 \mathrm{~K}$ by using a Faraday magnetic balance.

With the exception of $\left(\mathrm{C}_{5} \mathrm{H}_{5}\right)_{3} \mathrm{NpF}$, all compounds show a very similar behaviour in this temperature range (see Fig. 1).

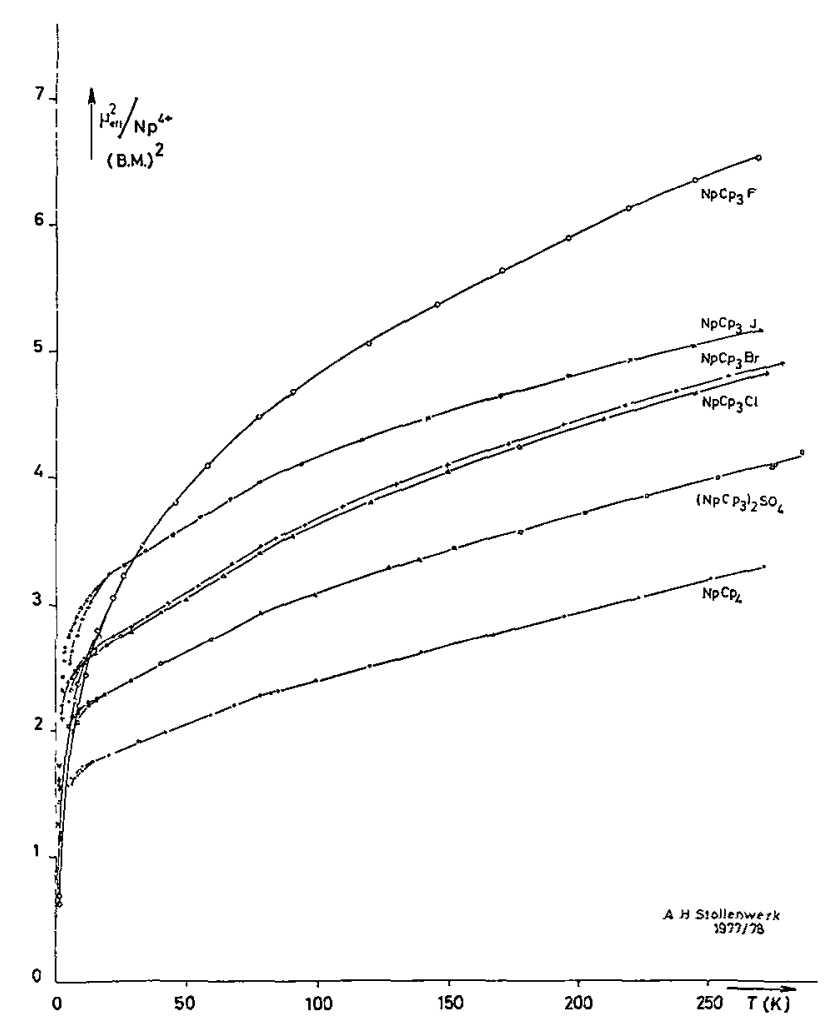

Fig. 1. - The average magnetic moments $\left(\mu_{\text {eff }}^{2}\right)$ of the neptunium compounds as a function of temperature. 
a) Between 15 and $100 \mathrm{~K}$ the temperature dependence of $\mu_{\text {eff }}^{2}=8.00 \chi T$ is a straight line corresponding to a second order Zeeman effect of the ground level with the next excited Stark component of the ${ }^{4} \mathbf{I}_{9 / 2}$ multiplet split by the crystal field.

b) Below $15 \mathrm{~K}$ the magnetic susceptibility of all compounds becomes field dependent as expected for magnetically active electronic ground states. A slight deviation of the magnetization curves from the Brillouin function was observed in the temperature region below $4 \mathrm{~K}$.

c) Above $100 \mathrm{~K}$ at least one more Stark level becomes thermally populated, but up to $300 \mathrm{~K}$ the free ion ${ }^{4} I_{9 / 2}$ magnetism is by far not reached.

The magnetic susceptibility curve of $\left(\mathrm{C}_{5} \mathrm{H}_{5}\right)_{3} \mathrm{NpF}$ differs considerably from those of its halide homolo- gues and suggests that self-association possibly occurs, as has been shown for $\left(\mathrm{C}_{5} \mathrm{H}_{5}\right)_{3} \mathrm{UF}[6]$.

4. 'H-NMR-investigations. - Nuclear magnetic resonance data for the cyclopentadienyl ring protons of actinide cyclopentadienyl compounds offer even more difficulties for interpretation, since while one of the two forms which contribute to the paramagnetic displacement varies with the magnetic susceptibility, the other term is proportional to the anisotropy of the magnetic susceptibility.

Our data obtained on $\left(\mathrm{C}_{5} \mathrm{H}_{5}\right)_{3} \mathrm{NpX}(\mathrm{X}=\mathrm{Cl}, \mathrm{Br}, \mathrm{I})$, for the inverse paramagnetic displacement versus temperature, show a Curie-Weiss behaviour above $240 \mathrm{~K}$ up to $340 \mathrm{~K}$ and indicate a normal Curie behaviour below $240 \mathrm{~K}$ down to $210 \mathrm{~K}$.

\section{References}

[1] Kanellakopulos, B., Bagnall, K.W., in MTP International Review of Inorg. Chem., Series 1, Vol. 7, Butterworths (University Park Press) 1972, p. 229-322 ; ADERHOLD, C. M., Dissertation, Universität Heidelberg, (1975) ;

Marks, T., Kolb, I. R., J. Am. Chem. Soc. 97 (1975) 27 ; Funushima, E., Larsen, S. D., Chem. Phys. Lett. 44 (1976) 285 ;

Amberger, H. D., J. Organomet. Chem. 116 (1976) 219.

[2] Soulie, E., Thèse, Université de Paris-Sud (1977).

Folcher, G., Marquet-Ellis, H., Rigny, P., Soulie, E. GoOdMAN, G., J. Inorg. Nucl. Chem. 38 (1976) 747.
[3] Stollenwerk, A., Klenze, R., Kanellakopulos, B., Paper to be presented at the NATO Advanced Study Institute Organometallics of the f-Elements, Urbino, Italy, Sept. 11 (1978).

[4] Dornberger, E., Kanellakopulos, B., Klenze, R., to be published.

[5] Baumgartner, F., Fischer, E. O., Kanellakopulos, B., Laubereau, P., Angew. Chem Int. Ed. 7 (1968) 634.

[6] Fischer, R. D., v. Ammon, R., Kanellakopulos, B, J. Organomet. Chem. 25 (1970) 123. 